\title{
Learning of Latvian Language in Pre-Schools in Linguistically Heterogeneous Situations
}

\author{
DDace Markus ${ }^{1}$ Dr. habil. philol.; Agrita Tauriṇa ${ }^{2}$ Dr. paed.; Tija Zīriṇa ${ }^{3}$ Dr. psych. \\ Liepaja University, Latvia \\ markus@latnet.lv¹; agritataurina@gmail.com²; zirina.tija@gmail.com³
}

\begin{abstract}
Topicality of the article is that the development of a child's speech today needs to become more important and be promoted, because increasingly teachers in pre-school face the situation of children entering the pre-school environment with poorly developed vocabulary and insufficient skills to make a request to be able to communicate effectively with peers and adults. The aim of the article is to study the promotion of the Latvian learning of children of pre-school age in the pedagogical process in theoretical and practical terms, by implementing various methods and through the provision of the educational environment. The research includes analysis of scientific literature and methodology for learning the Latvian language of children aged 5-6 years old in pre-school education institutions of Riga and Kurzeme, evaluating audio records, and qualitative analysis of the observed facts. Research question - how to improve the acquisition of Latvian language of native speakers and minority pre-school age children? The research was conducted in May and June 2019 and the data were received from 4 pre-school educational establishments in Kurzeme (75 records) and 5 pre-school educational establishments in Riga (75 records). Pre-school child language records were performed in groups with Latvian and Russian as the daily languages. On the basis of the results of an empirical study, the promotion of Latvian learning for children of pre-school age has been updated in the pedagogical process, by developing a knowledge-based environment appropriate to the approach of competence. To become more familiar with the reasons for improving a child's insufficient Latvian language, as well as to help find an objective view of the results of learning the Latvian language in the pedagogical process of implementing various methods, the experimental methodology for phonology, grammatical, (morpho) phonology and reading skills developed in the project, was used.
\end{abstract}

Keywords: Latvian language, pre-school age, competence-based approach.

\section{Introduction}

The State language in Latvia is Latvian language and good knowledge of Latvian language for children of any nationality is relevant for the successful study process at school.

Language is one of the main forms of national culture. Learning language in childhood depends directly and indirectly on the adults responsible for the overall psychological development of children at a given moment. Holistic approach to shaping the teaching and learning process of Latvian language bears favourably on learners' spiritual and physical development in both real and ideal pedagogical situations in pre-school education (Badjanova, Ilisko, 2014). American linguist and philosopher, N. Chomsky, indicates that language structure reveals human mental capacities and it includes knowledge of linguistics, philosophy and psychology (Chomsky, 2006).

The development of a child's speech today needs to become more important and be promoted, because increasingly teachers in pre-school face the situation of children entering the pre-school environment with poorly developed vocabulary and insufficient skills to make a request to be able to communicate effectively with peers and adults. Taking today's fast-growing trend of daily use of technology into account, as well as the great rush and busy work of parents, it should be acknowledged that a child is often not the winner in this situation and that the child's vocabulary is losing its pace of development. A. Vulane explains that for a variety of reasons, many parents are talking to a child less - both at an early age and in later years, in primary and later periods. Consequently, the child often remains alone in the cultural world that he needs to learn about, decipher and sort into what is valuable or less valuable (Vulane, 2007, 82).

Professor and famous expert in bilingual education, C. Baker, indicates: "Language lies at the heart of education, culture and identity. When a language dies, so does a considerable amount of culture, identity and knowledge that has been passed down from generation to generation through and within that language" (Baker, 2011, 46). This explanation reveals the interaction between language and culture, 
which is why the concern about Latvian language learning in pre-schools is theoretically based and to help better develop the necessary educational approach for language learning in pre-schools.

A. Vulane highlights the importance of the environment in learning the language; she explains that the daily cultural environment in which a child has to live is vital for personal development. It can be made up of toys, a world of colours and objects, as well as activities that help a child to watch, listen and read. Most importantly, however, as has long been acknowledged by psychologists, is ensuring that the child is in a loving and respectful environment. In the development of a child's emotional world, it is not only the caresses provided by adults, but also the tone and words of the adult voice (Vulane, 2007, 82).

The importance of the quality of language in the process of interaction with a child is stressed by $\mathrm{C}$. Baker. He indicates that asking interesting questions to a child, creating stories and rhymes could be a very good approach in encouraging the child to form his/her own words and phrases. It is necessary to encourage the child to speak, and not only listen to the parent's speech, because the child should be active in the process of interaction (Baker, 2007). This also reflects the truth about the use of digital devices, regarding the fact that they can only be helpful in speech development in the situation when they are used together with the adult, and not solely by the child.

In addition, multicultural aspects should be considered because globalization aspects influence the children's social environment and their inclusion in a globalized society (Andersone, Helmane, 2018). The teacher's role is essential to support effective learning in a multicultural environment. Linguistic diversity of children are relevant and teachers should know their students and their capacity to acquire knowledge (Moloney, Saltmarsh, 2016). One of the aspects for successful inclusion in the educational process is child's possibility to communicate with peers and well-developed language skills, which are of crucial importance in the child's socialization process.

The aim of the article is to study the promotion of the Latvian learning of children of pre-school age in the pedagogical process in theoretical and practical terms, by implementing various programmes and through the provision of the educational environment.

\section{Methodology}

The tasks of this study are as follows:

1) to perform a theoretical analysis of the scientific literature on the peculiarities of Latvian language acquisition of pre-school children in Riga and Kurzeme;

2) to carry out a study of children's audio recordings and to give a qualitative analysis of the obtained data.

Research question is - how to improve the acquisition of Latvian language of native speakers and minority pre-school age children?

A pedagogical experiment was carried out to clarify how to improve the acquisition of Latvian language of native speakers and minority pre-school age children. Prior to performing the study, signed statements were received from parents regarding support to explore the learning of the Latvian language of children and to implement children's speech records. The developed study methodology was harmonised by the Ethics Commission of Liepaja University. We can assure you that all ethical principles of a scientific study involving children aged up to 7 have been observed. In the study there have been used a theoretical research method - analysis of scientific literature and empirical methods methodology for learning the Latvian language of children aged 5-6 years old in pre-school education institutions of Riga and Kurzeme, evaluating audio records, and qualitative analysis of the observed facts. A new Latvian proficiency test for 5-6-year-olds has been developed and tested to establish readiness for school in Latvian during the period from May 2019 to June 2019. The study sample comprised 150 records obtained from 5-6-year-old primary school students from Kurzeme (4 pre-school educational establishments, 75 records) and Riga (5 pre-school educational establishments, 75 records). In each region Kurzeme and Riga there were 25 Latvian children from groups with Latvian language instruction, 25 Russian children from groups with Latvian language instruction and 25 Russian children from groups with Russian language instruction. Every record was done in a 20 minutes period. Each student was given a code. The children speech recordings obtained in Latvian proficiency test were analysed according to the following criteria: speech of dialogue, fluency, pronunciation, vocabulary, 
grammar and literacy skills. Children were asked to look at the test picture and describe it, answer the questions, create a narrative and read the sentence.

The evaluation of language level was represented in points and the following levels were defined:

0 points (insufficient level) - a child does not have or have very limited $(<5 \%)$ knowledge and skills;

1 point (low level) - minimal $(<25 \%)$ knowledge and skills;

2 points (average level) - average (> 50\%) knowledge and skills;

3 points (high level) - good (> $75 \%$ ) knowledge and skills.

Permits have been obtained from the State Children's Rights Protection Inspectorate, the Data State Inspectorate and the data protection specialist of the University of Liepaja to use materials developed or suitable for the Project (information letter to parents; consent form of parents/adoptive parents/guardians; speaking skills rating scale; Latvian test and its evaluation page; survey "Bilingual Child and Language Environment"). For the study to be carried out, parental consent was obtained for audio recordings.

\section{Results and discussion}

The role of teachers and parental cooperation in educating the child has now become essential in the educational changes phase of Latvia. The role of teachers and parents is to instil and support the child's interest in learning and understanding, promoting the desire for knowledge. Parents support the child in the learning process by:

- being interested in what the child learns by discussing it;

- developing cooperation relationships with teachers;

- supporting and building the child's autonomy;

- supporting the interests and issues of the child;

- targeted spending of time with the child;

- using everyday situations to learn;

- modelling positive behaviour, curiosity and positive attitudes towards learning.

The actions mentioned will strengthen the child's personality, create a sense of security and a full relationship between the child and the parents, as well as enable the child to develop the vocabulary (Es saprotu..., 2020).

Professor E. Hoff indicates the importance of adults using rich and different vocabulary in communication with a child. Vocabulary should include synonyms, epithets and comparisons to help the child in the language acquisition process. It will help to enrich the child's vocabulary much more quickly (Hoff, 2008). Her research of bilingual children makes the point that "language acquisition is not the easy or automatic result of minimal exposure plus maturation. Rather, language acquisition is the outcome of what the child does with substantial amounts of exposure, sustained by current use" (Hoff, 2020, 86).

A teacher should provide a pleasant and enthusiastic atmosphere so that a child goes to a pre-school educational institution with pleasure and interest. Pedagogical observations show that in such an atmosphere a child safely pursues a variety of activities with confidence, develops a particular skill, acquires knowledge and develops a certain attitude towards the immediate surroundings. However, if a child has an inaccurate pronunciation, and it is difficult to understand what is being said, then the collaborative skills with peers and engagement in day-to-day activities will be complicated. Therefore, the child has an inherent need to express his/her desires, needs, and the words he/she has learnt, as well as the forming of sentences is essential, leading to the development of a child's personality in various aspects.

Professor D. Markus highlights the importance of child and adult emotional communication in the speech process. The more a child develops language, the richer the child's vocabulary of words and forms becomes, and more broadly reflective, diverse and deeper his/her thinking develops - words encourage new thinking patterns and create associations. So, a limited vocabulary does not only stifle expression but also impedes the child's thinking (Markus, 2007).

B.Z. Pearson stresses that written materials, such as children's literature, can be a factor that helps in language acquisition and facilitates language development and retention at an early age (Pearson, 2007). This is an important aspect in many families because reading books with children at home nowadays tends 
not to be done as often as before because many families spend their free time in front of the TV or using digital devices. The lack of conversation and reading can lead to a delay in learning the language.

A group of researchers from the University of South Florida indicated that the use of digital devices in pre-school by young children can be very helpful in fine motor coordination, and excellent in the facilitation of storytelling (Decat et al., 2019). It means that digital technologies can be purposefully used in the educational process in pre-schools. Still, the American child psychologist points out that technologies are changing our lives, they are moving on much faster than before, and children are being hurried in their development (Elkind, 2006).

Self-guided learning is promoted in the implementation of the competency approach. This means that a child is invited to assess his/her performance, to listen to what other children have said and to add to their experience, as well as plan, organise and evaluate. This is why it is necessary to support the child in language learning, thereby also promoting the skills of cooperation, critical thinking and civic participation. Competence is complex: it includes knowledge, skills and habits related to motivation and will. Therefore, one of the key challenges in reviewing the content of training is to reduce fragmentation and to reduce the learning from real life situations and the development of isolated skills. Succession, regularity and integrity are the basic principles on which the creation of the new content is based (Es saprotu..., 2020).

In order for every child to acquire sufficient Latvian language skills for the successful commencement of training at the elementary school level, the reinforced acquisition of the Latvian language in minority pre-school programmes is envisaged. Guidelines state that in minority pre-primary education programmes, the learning of the Latvian language in an integrated learning process and day-to-day contact, in line with the development of children, should be promoted every day to achieve the results of the language learning field in a rapid manner. The Latvian language is determined as a means of communication in the day-to-day learning process or in the play session, but at the same time, the results to be achieved are also intended in the acquisition of the minority language (Es saprotu..., 2020).

J. Brodin, K. Renbland points out that the need for different modes to support communication is extensive. Pre-school plays a key role in child development, and it includes both day care and kindergarten. All children, typical and atypical, attend an inclusive pre-school, and the motto in Sweden is 'a (pre)school for all'. They focus on finding out if reading aloud and storytelling could enhance children's communication development and how, as reported in many global studies (Brodin, Renbland, 2020). Pre-school is expected to stimulate children's learning and development from a holistic point of view, and most children between one- and five years old attend pre-school. The demands on pre-school teachers are growing in pace with the increasing number of immigrant children arriving to Sweden without being able to speak the Swedish language. This is a challenge for the pre-school system. The goals in pre-school are many and the teachers are responsible for attaining the goals 'to the extent possible' (Brodin, Renbland, 2020). In implementing the competence approach, children engage in activities promoting self-directed learning, the child appreciates the results of their work and others' work, better understands what is successful and what needs more focus, and that challenges must be targeted.

Cabinet of Ministers Regulation No. 716 "Rules regarding guidelines for State pre-primary education and samples of pre-primary education programmes" states that "the aim of implementing the content of pre-school education is to develop an inquisitive, creative and vibrant child who has a healthy, safe and active life, works independently, learns with interest and pleasure, gaining experience of herself, others, the surrounding world and interaction within it" (Regulations Regarding ..., 2018).

Every child has the right to develop his/her potential and this is a question about the equity provided by pre-school education settings. Equity ensures that a child can develop intellectual, social, emotional, linguistic and physical capabilities (Friedman, Mwenelupembe, 2020). A competence-based approach could be of great use in reaching this goal.

Z. Anspoka, I. Irbe, D. Liepina and A. Miesniece note that an appropriate learning environment is essential in the organisation of the pre-primary education process. The learning environment needs to be motivational so that every child has a desire to get involved. The environment needs to be dominated by relationships that promote the desire to improve the outcome of work, enable each other to learn from one another with a dignified attitude in referencing errors and shortcomings. In pre-school, good learning outcomes cannot be achieved in a competitive environment where formal results are important, where 
social comparisons occur, children are divided into groups by capacity, and where the learning and evaluation process places emphasis on the right answers. In the process of learning the intended content it is important to take into account the fact that the educational objectives are important for the child and that they are involved in establishing them (Anspoka et al., 2020).

This is achieved by the teacher through the targeted planning of the child's activities, providing the necessary materials and means of training by meaningfully asking, negotiating, analysing situations, tackling problems together, offering productive tasks, diverse and carefully selected examples, situations and demonstrations. In the training process, the teacher shall involve every child, providing adequate support and monitoring for each child.

Researchers V. Grøver, V. Rydland, J.E. Gustaffson and C.E. Snow emphasize teachers' professional competence in engaging children in conversations around books as a mechanism for promoting language growth. It is very helpful for children whose language environment in pre-school and family is different to acquire new vocabulary (Grøver et al., 2020). The study of researchers from UK indicates the importance of books that contain personalized content for a child. They have concluded that books, which are personalized, can better facilitate young children word's acquisition. Personalization is indicated as an important factor in child vocabulary development (Kucirkova, Messer, Sheehy, 2014). In the reading process adults play a central role by asking questions and providing positive feedback of child speech (Lenhart et al., 2020). Adult verbal responsiveness is a promoting factor in successful vocabulary development and learning process of new words (Blewitt, Langan, 2016). These findings can be helpful in the organization of the educational process in Latvian pre-schools where children learn Latvian language.

Teacher and child conversations are important factors in language acquisition. The pattern of teacher use of elicitations and extension in communication with a child can be helpful to his/her vocabulary growth (Cabell et al., 2015). Storytelling also could be used in vocabulary learning. Children engagement in interesting storytelling have a positive effect on vocabulary development (Vaahtoranta et al., 2018).

Dialogue involving the exchange of reasons for and against claims could be seen as a prototypical form of dialogue itself. Although discourses exchanged in face-to-face interactions draw on non-verbal communication and may even be performed using only gestures, pictures or signs, we shall assume that dialogues are interactions where language is predominant (Schwarz, Baker, 2016, 73).

Exposure to speech characterised by lexical diversity provides children with more opportunities to expand their vocabulary by learning new words. Hearing a different word not only enables a child to learn the meaning of this word but also exposes the child to various phonological patterns. Additionally, exposure to a variety of words allows children to hear words in different contexts or with different descriptions, which may help children learn about that word. For instance, the same word (e.g., "ball") may be used in two different sentences (e.g., "The ball is round and red" and "I'm rolling the ball with you!") to convey different information about that word. This diversity also helps a child learn more about that word. Similarly, if a caregiver uses a variety of words in a sentence or phrase, the child may know some but not all words that the caregiver says. Knowing other word meanings in a sentence increases possible interpretations of a new word and thus, the lexical diversity of the sentence may contribute to children learning the meaning of a new word. These studies highlight the importance of lexical diversity in the speech of caregivers (Zauche et al., 2016, 323).

The children speech results obtained in Latvian proficiency test were following. 

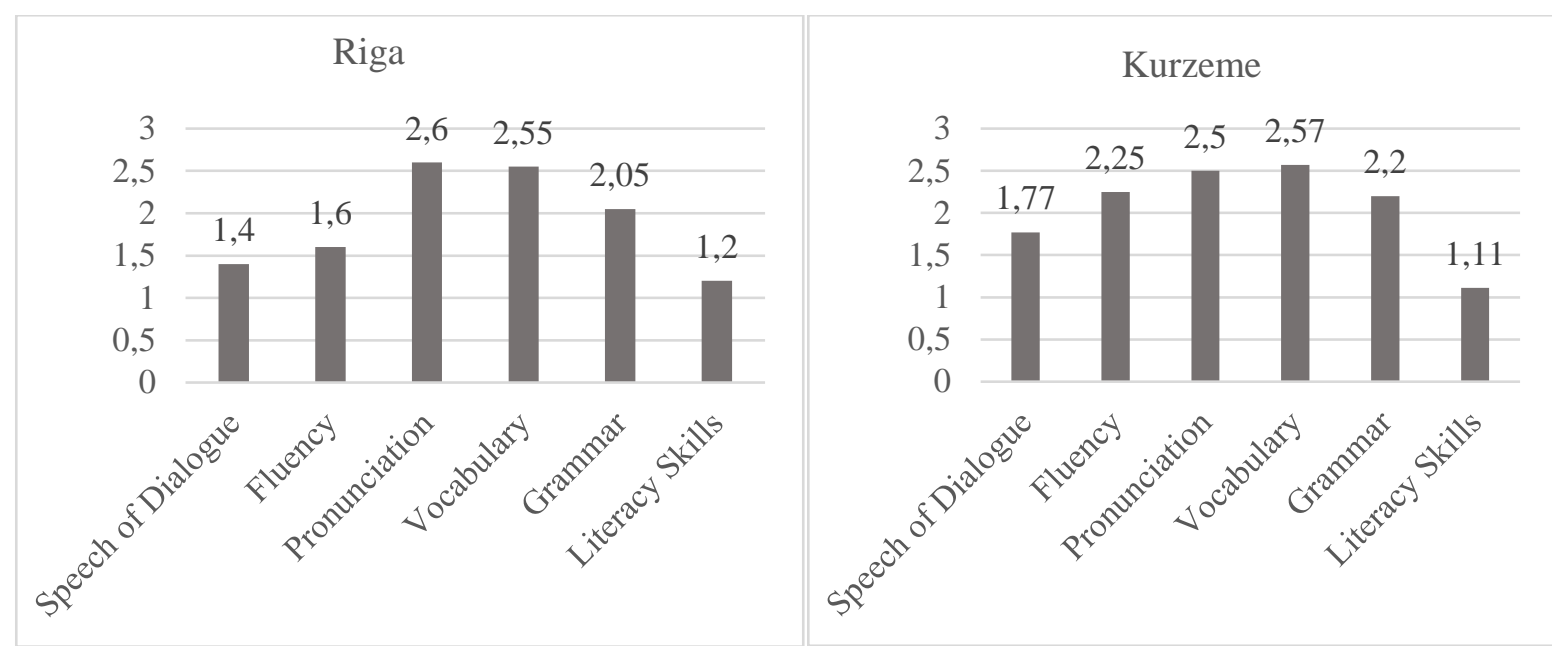

Figure 1. Skills for learning the Latvian language of native Latvian speaking children in Riga and Kurzeme (values represent children language level indicated in points).

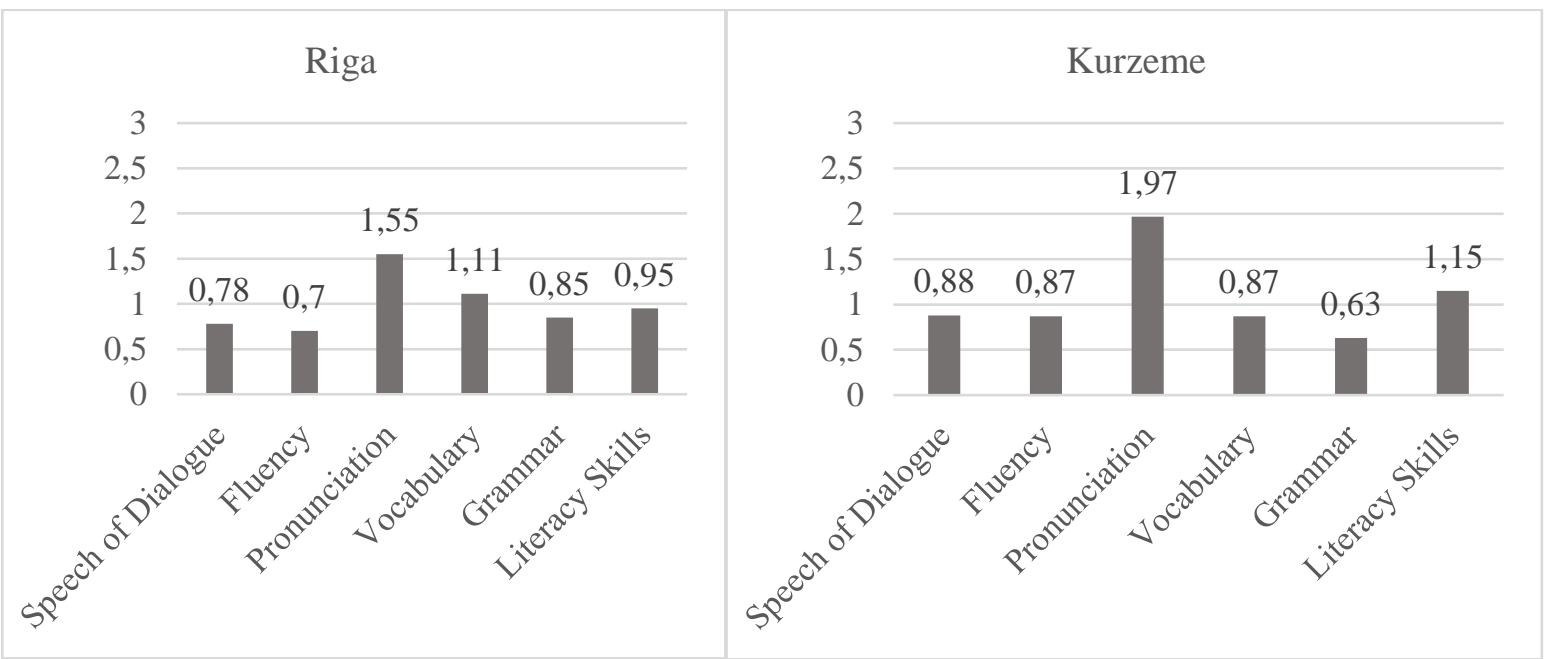

Figure 2. Latvian language skills of minority children in Riga and Kurzeme in groups with Russian language daily (values represent children language level indicated in points).

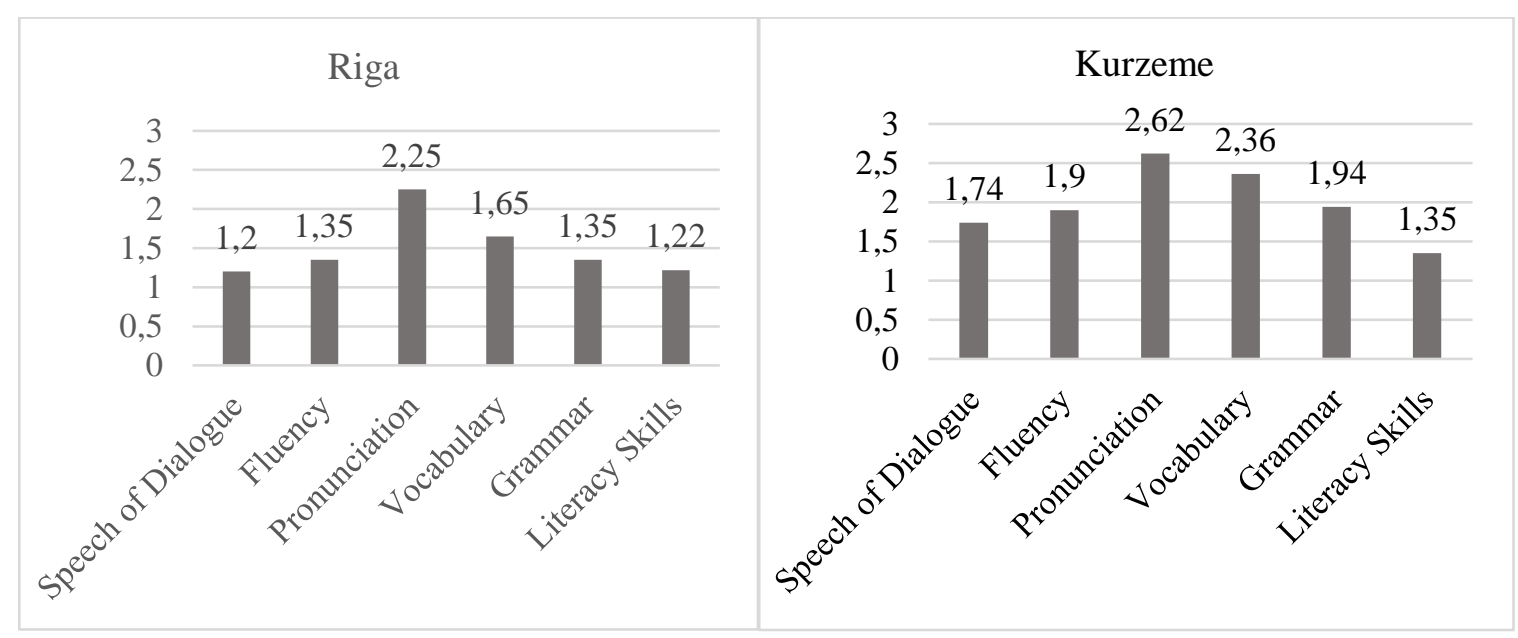

Figure 3. Latvian language skills of minority children in Riga and Kurzeme in groups with Latvian language daily (values represent children language level indicated in points). 
The results obtained highly demonstrate that, for children visiting groups using the Latvian language every day, the Latvian language skills are significantly better than the language skills of minority children visiting groups using Russian-dominated language every day (Figures 1,2,3).

If a child's family is bilingual, a child in a group with a daily dominant Russian language may also have good results learning Latvian in reality; however, most of these children come from families who speak Russian every day, so often the only place to practice Latvian is in a pre-school education institution.

\section{Conclusions}

The following conclusions crystallized as a result of the theoretical analysis:

- language is an important part of culture and identity, so it is important to pay attention to its acquisition in preschool;

- a holistic approach to Latvian language teaching has a positive effect on learners' mental and physical development;

- language structure learning develops human mental capacities;

- the role of the teacher is essential to support the child's effective learning in a multicultural environment and integration into a globalized society;

- nowadays increased attention is paid to cooperation between teachers and parents to inspire and support the child's interest in learning, to discuss the child's developmental difficulties, if there are any, to promote the child's independence and autonomy, which will expand the child's vocabulary and create a sense of security;

- providing a pleasant and enthusiastic atmosphere in pre-school creates a motivation for the child to come to pre-school, live with joy and learn language through play, which later ensures successful integration into primary school.

The results of the research by qualitatively analysing the audio recordings of children's speech are as follows.

- The best results in pre-school can be achieved in child pronunciation development. Children whose mother tongue is different also show the best performance directly in the Latvian language. This phenomenon is the opposite of what is observed in adult speech, because when you learn a second language under the influence of the stereotype of the mother tongue, the differences in pronunciation persist for a long time. During the study, we observed that minority children do not have trouble imitating the Latvian language pronunciation, even if the child does not know the meaning of the word. Therefore, for second-language learning, pre-school age is very appropriate.

- Expanding the vocabulary is the next result to be reached, but here the rating is varied.

- For those children who visit groups using the Latvian language (as native and second), the Latvian vocabulary is substantially richer, while for those minority children who visit groups using Russian every day, the Latvian vocabulary is very poor and only covers some of the most commonly used names in the household, and they are usually nouns in the nominative case.

- Some parents do not pay much attention to children's reading skills at pre-school age, believing they will be learnt through school training. The recommendation is to provide a real bilingual environment for minority groups of children.

- Over the last two years, the introduction of new education guidelines is being implemented in preschool, which provides for a significant increase in the use of Latvian language also in minority pre-primary education institutions with an improved methodology for learning the Latvian language.

- Various methods were used during the research - reading aloud, asking purposeful questions to children, forming dialogues, activating cooperation with other children in the form of games; phonology, teaching grammar and stimulating reading, which promoted the development of curious, creative and dynamic child, which enjoy learning with interest gaining their own life experience. 
- The results of the study give an answer to the issue - to ensure more successful integration of children into school, the development of the Latvian language should be strongly promoted in the pre-school education institutions in contact with children.

\section{Acknowledgments}

The research team is grateful to the Latvia State Research Programme "Latvian language" No. VPPIZM-2018/2-0002 for the considerable support during the project implementation (2018 - 2019).

\section{Bibliography}

1. Andersone R., Helmane I. (2018). Interdisciplinary Education in Multicultural Environment. In V. Dislere (Ed.), The Proceedings of the International Scientific Conference Rural Environment. Education. Personality, 11. Jelgava: LLU, 25-32. Retrieved from https://llufb.1lu.lv/conference/REEP/2018/Latvia_REEP_2018_proceedings_ISSN2255808X-25-32.pdf

2. Anspoka Z., Irbe I., Liepina D., Miesniece A. (2020). Mācības bilingvāli un latviešu valodā. Rokasgrāmata pirmsskolas pedagogiem [Bilingual and Latvian Teachings. Manual for Pre school Teachers]. (2020). Retrieved from https://maciunmacies.valoda.lv/wpcontent/uploads/2020/08/LVA_A4_rokasgraamata_WEB_gatavs.pdf (in Latvian)

3. Badjanova J., Ilisko Dz. (2014). Holistic philosophy based teaching approaches in Latvian primary schools: Primary education teachers' view. In V. Dislere (Ed.), The Proceedings of the International Scientific Conference Rural Environment. Education. Personality (REEP), 7. Jelgava: LLU, 22-28. Retrieved from https://lufb.llu.lv/conference/REEP/2014/Latvia-UnivAgricult-REEP-2014proceedings-22-28.pdf

4. Baker C. (2007). A Parents' and Teachers' Guide to Bilingualism ( $3^{\text {rd }}$ ed). Clevedon: Multilingual Matters Ltd.

5. Baker C. (2011). Foundations of Bilingual Education and Bilingualism (5 $5^{\text {th }}$ ed.). Bristol: Multilingual Matters Ltd.

6. Blewitt P., Langan R. (2016). Learning words during shared book reading: The role of extratextual talk designed to increase child engagement. Journal of Experimental Child Psychology, 150, 404-410. doi: 10.1016/j.jecp.2016.06.009

7. Brodin J., Renbland K. (2020). Improvement of preschool children's speech and language skills. Early Child Development and Care, 190(14), 2205-2213. doi: 10.1080/03004430.2018.1564917

8. Cabell S.Q., Justice L.M., McGinty A.S., DeCoster J., Forston L.D. (2015). Teacher-child conversations in preschool classrooms: Contributions to children's vocabulary development. Early Childhood Research Quarterly, 30. 80-92. doi: 10.1016/j.ecresq.2014.09.004

9. Chomsky N. (2006). Language and Mind ( $3^{\text {rd }}$ ed.). Cambridge: Cambridge University Press.

10. Decat E., Damjanovic V., Branson S., Blank J., Berson I. (2019). Using Touch Technology to Foster Storytelling in the Preschool Classroom. Journal of Inquiry \& Action in Education, 10(2), 1-22. Retrieved from https://digitalcommons.buffalostate.edu/jiae/vol10/iss2/1

11. Elkind D. (2006). The Hurried Child. Cambridge, MA: Da Capo Press.

12. Es saprotu, tätad zinu - varu - gribu - protu [I understand - I know - can - want - know]. (2020). Valsts izglìtíbas satura centrs. Retrieved from http://skola2030.lv/admin/filemanager/files/2/Skola2030_buklets_Pirmsskola.pdf (in Latvian)

13. Friedman S., Mwenelupembe A. (Eds.). (2020). Each and Every Child: Using an Equity Lens When Teaching in Preschool. The National Association for the Education of Young Children.

14. Grøver V., Rydland V., Gustaffson J.E., Snow C.E. (2020). Shared Book Reading in Preschool Supports Bilingual Children's Second-Language Learning: A Cluster-Randomized Trial. Child Development, 91(6). 2192-2210. doi: 10.1111/cdev.13348

15. Hoff E. (2008). Language Development ( $4^{\text {th }}$ ed.). Cengage Learning.

16. Hoff E. (2020). Lessons from the study of input effects on bilingual development. International Journal of Bilingualism, 24(1), 82-88. doi: 10.1177/1367006918768370

17. Kucirkova N., Messer D., Sheehy K. (2014). Reading personalized books with preschool children enhances their word acquisition. First language, 34(3), 227-243. doi: 10.1177/0142723714534221 
18. Lenhart J., Suggate S., Lenhard W., Vaahtoranta E. (2020). Shared-reading in small groups: Examining the effects of question demand level and placement. Cognitive Development, 55. doi: 10.1016/j.cogdev.2020.100914

19. Markus D. (2007). Bērns runā kultūras pasaulē [Child speaks in the cultural world]. Rīga: Rasa ABC. (in Latvian)

20. Moloney R., Saltmarsh D. (2016). 'Knowing Your Students' in the Culturally and Linguistically Diverse Classroom. Australian Journal of Teacher Education, 41(4). 79-93. doi: 10.14221/ajte.2016v41n 4.5

21. Pearson B. Z. (2007). Social Factors in Childhood Bilingualism in the United States. Applied Psycholinguistics, 28(3), 399-410. doi: 10.1017/S014271640707021X

22. Regulations Regarding the State Guidelines for Pre-school Education and the Model Pre-school Education Programmes. (2018). Cabinet of Ministers. Cabinet Regulation No. 716. Retrieved from https://likumi.lv/ta/en/en/id/303371

23. Schwarz B.B., Baker M.J. (2016). Dialogue, argumentation and education: History, theory and practice. New York, NY: Cambridge University Press.

24. Vaahtoranta E., Suggate S., Jachmann C., Lenhart J., Lenhard W. (2018). Can explaining less be more? Enhancing vocabulary through explicit versus elaborative storytelling. First language, 38(2), 198-217. doi: $10.1177 / 0142723717737452$

25. Vulane A. (2007). Deminutīvs bērna emocionālajā pieredzē. Vecuma grupu valodas ìpatnības Latvijā: Lingvistiskais, sociālais un kultūras aspekts [Deminutive in a child's emotional experience. Special features of the age group language in Latvia: Linguistic, social and cultural aspects], 79-91. Rīga: Izglīitības soḷi. (in Latvian)

26. Zauche L.H., Thul T.A., Mahoney A.E.D., Stapel-Wax J.L. (2016). Influence of language nutrition on children's language and cognitive development: An integrated review. Early Childhood Research Quarterly, 36(3), 318-333. doi: 10.1016/j.ecresq.2016.01.015 